\title{
Fronteiras e pertenças: representações sociais e dinâmicas identitárias do tráfico de drogas na revista Veja (1968-2010) ${ }^{1}$
}

\author{
Borders and belongings: social representations and identity dynamics of \\ drug trafficking in Veja magazine (1968-2010) \\ Flaviane da Costa Oliveira ${ }^{2}$ \\ Ingrid Faria Gianordoli-Nascimento ${ }^{3}$ \\ Thayna Larissa Aguilar dos Santos ${ }^{4}$ \\ Janaína Campos de Freitas ${ }^{5}$
}

\begin{abstract}
RESUMO: Este trabalho buscou compreender o processo de construção de representações sociais do tráfico de drogas ao longo da história recente do país, acessando dinâmicas identitárias envolvidas. Nosso interesse recai sobre as produções da mídia de massa e seus impactos nas relações sociais e desigualdades tão marcantes em nossa sociedade. Este estudo documental reuniu matérias da revista Veja, do período entre 1968 e 2010, relativas ao tema tráfico de drogas. O corpus foi submetido à análise lexical desenvolvida com o auxílio do software ALCESTE. O procedimento de Classificação Hierárquica Descente apresentou sete classes, organizadas em dois grandes grupos, indicando uma dinâmica intergrupal, que sinaliza discursos de um endogrupo e de um exogrupo. Tanto no cenário internacional como no nacional, a necessidade de proteção da identidade social levou à construção de representações sociais do tráfico de drogas como algo que pertence ao estrangeiro ou ao grupo de fora. Assim, as periferias do globo ou das grandes cidades passam a ser vistas como reservatório do risco das drogas, o que se expressa de forma emblemática nas favelas e prisões. A maior parte das matérias se organiza em torno de argumentos técnico-científicos, que embasam estereótipos e preconceitos. A mídia apresenta-se, portanto, como importante instrumento da disseminação de uma versão dos fatos sociais, contribuindo para a construção do conjunto de significados atribuídos ao fenômeno, materializando personagens marginalizados e sem controle que assolam o imaginário social.
\end{abstract}

Palavras-chave: representações sociais; identidade social; revista Veja; tráfico de drogas; ALCESTE.

ABSTRACT: This study investigated the process of construction of social representations of drug trafficking along the country's recent history, accessing identity dynamics involved. Our interest is with the mass media productions and its impact on social relations and inequalities as striking in our society. This documental study has gathered materials from magazine Veja, in a period between 1968 and 2010, relating to the drug trafficking issue. The corpus was submitted to a lexical analysis developed with the support of the software ALCESTE. The descendent hierarchical classification procedure presented seven classes, organized in two groups, indicating an intergroup dynamics, that points out the discourses of an ingroup and an outgroup. Considering both national and international scenarios, the need for social identity protection led to the fabrication of drug trafficking social representations as something that belongs to the foreigner

\footnotetext{
${ }^{1}$ Apoio e financiamento: CAPES, FAPEMIG.

2 Mestre em Psicologia pelo Programa de Pós-Graduação em Psicologia da Universidade Federal de Minas Gerais; Bolsista de Mestrado da Coordenação de Aperfeiçoamento de Pessoal de Nível Superior (Capes) - Belo Horizonte, MG, Brasil. Email: flavianecoliveira@gmail.com.

3 Doutora em Psicologia; Coordenadora do Programa de Pós-Graduação em Psicologia da Universidade Federal de Minas Gerais e Docente do Departamento de Psicologia da Universidade Federal de Minas Gerais - Belo Horizonte, MG, Brasil.

${ }^{4}$ Graduanda no curso de Psicologia da Universidade Federal de Minas Gerais; Bolsista de iniciação científica da Fundação de Amparo à Pesquisa de Minas Gerais (FAPEMIG) - Belo Horizonte, MG, Brasil.

${ }_{5}^{5}$ Mestranda em Psicologia pelo Programa de Pós-Graduação em Psicologia da Universidade Federal de Minas Gerais - Belo Horizonte, MG, Brasil.
} 
or to the outer group. Thus, the peripheries of the globe or the big cities, come to be seen as a risk to be a reservoir of drugs, which is expressed in symbolic form in the slums and prisons. Most of the material is organized around technical and scientific arguments that support stereotypes and prejudices. The media presents itself, therefore, as important means of disseminating a version of social factors contributing to the construction of the set of meanings attributed to the phenomenon, materializing marginalized characters and uncontrolled plaguing the social imaginary.

Keywords: social representations; social identity; Veja magazine; drug trafficking; ALCESTE.

\section{Introdução}

Quando nos debruçamos sobre os documentos produzidos pela mídia de massa, problematizando a produção das informações, seu direcionamento e público consumidor, tal análise revela alguns aspectos relativos à lógica da relação intergrupos presente nas sociedades, e deste modo, os discursos sinalizam que determinados objetos ou elementos representacionais são valorizados, enquanto outros são percebidos como ameaça pelo grupo de pertença (Tajfel, 1983). Enquanto registro e testemunha da história (Souza \& Menandro, 2007) a mídia impressa merece destaque, sendo fonte privilegiada para pesquisa nas ciências humanas e sociais.

Este trabalho focaliza um dos problemas sociais com maior expressão nos meios de comunicação brasileiros, o tráfico de drogas. O tratamento dado ao tema pelos veículos de imprensa demarcou historicamente, um perfil para as classes que seriam responsáveis pela origem, disseminação e violência inerentes ao tráfico (Zaluar, 1994a; Cruz Neto, Moreira \& Sucena, 2001).

Como constatado por Zaluar (1994a) e Cruz Neto, Moreira e Sucena (2001) durante as últimas décadas do século $X X$, a presença da criminalidade nas classes sociais favorecidas seguiu pouco divulgada nas coberturas midiáticas (Ramos \& Paiva, 2007), em contrapartida, as publicações vinculadas a crimes ocorridos nas periferias ganharam cada vez mais espaço nos noticiários. As escassas condições de vida e baixa renda da grande maioria da população intensificam formas de segregação. Aos poucos a condição econômica passa a ser utilizada socialmente como justificadora do processo de criminalização da pobreza (Zaluar, 2004; Coimbra, 2001b) e as relações entre pobreza e tráfico de drogas, ganham ares de interdependência e auto explicação.

De fato, as estatísticas governamentais dão conta de números crescentes de registros de crimes vinculados ao tráfico de drogas $^{6}$ (Brasil, 2009), e são as classes pobres o estrato da população que lida diretamente com as repercussões do cotidiano de violência gerado pelos conflitos "comerciais" entre traficantes (Zaluar, 2004). Não se trata, portanto, de negar os números oficiais, mas de problematizar os processos de estigmatização e exclusão social, imbricados na construção histórica de depositários (Joffe, 1994/2009) para determinados objetos sociais ameaçadores.

Neste sentido, esta investigação buscou compreender o processo de construção de Representações Sociais (RS) do tráfico de drogas ao longo da história recente do país, e as

6 Entre os anos de 2004 e 2007, os registros de crimes de tráfico de drogas ilegais, aumentaram no território nacional de um total de 31.368 para 47.747. Em relação ao total de crimes registrados, estes números representam uma média de $0,8 \%$ dos registros entre os anos. Em comparação com cada 100.000 habitantes, os registros subiram de 17,46\% em 2004, para 29,62\% em 2007. 
dinâmicas identitárias intergrupais, que permeiam as relações sociais e desigualdades vinculadas ao fenômeno.

Ao fundamentar-se na teoria das representações sociais (Moscovici, 2009, 2012), este trabalho pretende problematizar o tema tráfico de drogas enquanto uma realidade "desconhecida" e ameaçadora que despertou, e continua despertando medo, em diferentes estratos da população, especialmente entre aqueles que controlam os veículos de imprensa. Ao isolar objetos sociais para fora do grupo próprio, os grupos sociais constroem representações sociais que têm por função proteger a identidade social do mesmo (Moscovici, 2012; Wagner, 2000). Deste modo, os grupos sociais que integram a sociedade, nos diferentes tempos e espaços, buscam recursos de compreensão da realidade na tentativa de evitar situações de ameaça e desequilíbrio.

Os processos de categorização, comparação e diferenciação estão na base da construção da identidade social dos grupos (Tajfel, 1983), perpassando, portanto, a discussão que empreendemos neste trabalho. Como destacado por Andrade (2000) e Santos (2000), as representações sociais reapresentam objetos sociais a partir da expressão das relações identitárias dos grupos. Tais processo parecem estar na base da construção das representações sociais do fenômeno investigado.

\section{O proibicionismo e a origem do tráfico de drogas}

Para mapear as representações sociais do fenômeno do tráfico de drogas, faz-se necessário conhecer os aspectos históricos que construíram as relações sociais em torno das drogas, seu comércio e proibição. Pesquisas em variadas sociedades sinalizam os diferentes lugares sociais destinados à droga (seu conceito, sua função/papel e seu controle) (Escohotado, 1998; Araújo, 2012). Aspectos culturais, políticos e sociais desencadearam proibições que levaram à regulação jurídica e a criminalização das atividades de uso e comércio de drogas, em diferentes partes do globo. Desta forma, a composição da categoria droga revela inúmeras ambiguidades, indicando algumas destas influências históricas.

Segundo Vargas (2008) há variadas hipóteses para a origem do termo droga, possivelmente, vinda do "latim drogia, do irânico daruk e do árabe durâwa e do celta druko" (p. 42), além da possibilidade de origem holandesa do termo, derivada da expressão "droghe vate" (p. 42), traduzida por "barris de coisas secas" (p. 42). Segundo o autor, esta última hipótese teria relação com o período das grandes navegações, onde o contato entre europeus e outros povos no final da idade média teria levado a identificação das drogas como substâncias exóticas ou especiarias que provocariam sensações prazerosas (Vargas, 2008). Ainda, não haveria, portanto, uma conotação negativa para o uso de drogas, e suas propriedades científicas não eram absolutamente conhecidas.

Segundo Rodrigues (2003) a utilização do termo droga pelos meios de comunicação, nas conversações diárias e também em publicações científicas revela imprecisões. Estas indefinições são apontadas como mecanismo de generalização, que levam ao agrupamento de substâncias com diferentes propriedades e usos em um grupo único, o que favorece seu combate nos países que criminalizaram seu consumo ou tráfico.

O estudo da origem desta categoria de substâncias revela inúmeras ambiguidades, tais como apontado por Escohotado (1998). O autor menciona a origem do termo fármaco, a partir do grego phármakon que indica ambiguamente remédio e veneno, ou seja, aquilo que pode curar ou matar a depender de seu uso. Assim, destaca que a utilização de drogas 
marca a história de diferentes civilizações, mudando-se apenas os substratos selecionados e as diferentes funções que estas substâncias assumem dentro das culturas, tais como: elementos de rituais de purificação, forma de contato com divindades, práticas de socialização, fuga da realidade, dentre outras práticas.

A tolerância ou combate ao uso e ao tráfico de drogas, em diferentes contextos, foram influenciados por determinantes históricos, sociais, econômicos e políticos. Escohotado (1998) acentua que o consumo de drogas não é um fenômeno excepcionalmente contemporâneo, mas histórico, sendo recente a transformação do uso e comércio em práticas que colocam em risco a organização da sociedade como a conhecemos, tanto pelos prejuízos pessoais aos usuários e seus familiares, quanto em termos econômicos e sociais. $\mathrm{Na}$ mesma direção destas reflexões, Feffermann (2006) e Velho (1994) chamam atenção para o aspecto cultural que define as substâncias apontadas como drogas nos diferentes tempos e realidades.

Segundo Rodrigues (2003) os questionamentos sobre a legalidade das drogas, ou seja, a discussão sobre a proibição-liberação de seu uso e comércio passaram a figurar no cenário internacional na virada dos séculos XIX e XX. O autor aponta que ainda na primeira década do século XX, não havia, no Brasil, qualquer questionamento sobre o uso de drogas. No entanto, com a participação do país em convenções internacionais sobre o tema e conseguinte influência do posicionamento norte-americano de repressão às drogas, ideias de proibição começam a ser problematizadas. Durante o século XX, a influência norteamericana foi marcante na política de combate às drogas no Brasil.

Dentre outros, o fator religioso é apontado como determinante na tomada de posicionamento da política e da sociedade americana frente ao consumo de drogas (Escohotado, 1998; Rodrigues, 2003, Araújo, 2012). No início do século XX, a postura proibicionista associa-se à "tradição puritana do protestantismo" (Rodrigues, 2003, p. 26) disseminando ideias moralistas voltadas principalmente ao combate da prostituição, dos jogos de azar e do consumo de álcool na sociedade americana. Ao longo da primeira metade do século XX, várias leis americanas incidiram sobre as drogas proibindo-as ou controlandoas, tais como, Harrison Narcotic Act (Lei Harrison) de 1914, a Lei Seca de 1919, Marijuana Tax Act (Lei Tributária sobre a maconha) de 1937. Além do movimento do legislativo há uma mobilização social que leva ao processo de exclusão de grupos ameaçadores, erigindo-se novas fronteiras internas e externas na defesa contra o tráfico de drogas.

Durante o século XX as ideias proibicionistas americanas são espalhadas internacionalmente, e nas fronteiras internas revelam novos contornos a face do foco de ameaça: 'comportamentos desviantes' levados à cabo por 'indivíduos perigosos', notadamente negros ('cocainômanos agressivos'), mexicanos ('indolentes usuários da maconha'), chineses ('introdutores do ópio'), irlandeses e eslavos ('bêbados inveterados') (Rodrigues, 2002, p. 70).

No Brasil apenas em 1921, com a criação do Decreto $n^{\circ} 14.969$, que o país formalizou legislação específica sobre os usos não-médicos de substâncias psicoativas, tipificando as penalidades para seus vendedores e o tratamento para viciados, dando início à disseminação de um ideário proibicionista, assentado em argumentos de risco à saúde pública (Rodrigues, 2003). Em 1932 com a aprovação da Consolidação das Leis Penais, o Art.159 deste documento, passa a tratar explicitamente da conduta de tráfico de drogas ilícitas. Durante o governo de Getúlio Vargas (1930-1945), com as alterações do Código Penal, em 1940, o Art. 281 passou a definir a política sobre drogas, apontando seu comércio como crime contra a saúde pública. Em todas estas legislações, ainda não havia criminalização do usuário, apenas 
do traficante de drogas (Avelino, 2010). O número de usuários de drogas no Brasil começou a crescer já nas primeiras décadas do século XX. No entanto, os órgãos oficiais e pesquisadores não possuem levantamentos do período que detalhem a dimensão do problema. Mesmo os registros jornalísticos ainda não enfatizavam a questão.

A realização em 1961 da Convenção Única de Narcóticos, organizada pela ONU em Nova York (EUA), buscou centralizar as diretrizes internacionais de combate às drogas (Araújo, 2012). Esta convenção teria influências diretas nas reformas da legislação brasileira sobre drogas, refletindo-se no tratamento legal dos usuários de drogas, que passaram a ser criminalizados juntamente com os traficantes, a partir do Decreto 385 de 1968 que alterou o Art.281 do Código Penal. Uma ação legislativa que acompanha o recrudescimento do Regime Militar brasileiro (1964-1985), que naquele momento visava aumentar o controle sobre as ações juvenis, grupo social identificado como principal usuário de drogas e como contestador da ordem política vigente.

Nos EUA, para centralizar as práticas de controle das drogas o governo americano criou órgãos especiais ao longo das décadas de 1960 e 1970, o que se consolidou com a criação em 1974, do Drug Enforcement Administration (DEA) responsável por coordenar ações internas e externas de combate às drogas nos EUA e em outros países, inclusive no Brasil. As políticas dos governos americanos de Richard Nixon (1969-1974), Ronald Reagan (1981-1984 e 1985-1989) e George Bush (1989-1993) foram essenciais na construção social do tráfico de drogas como principal inimigo da sociedade americana, devendo, portanto, ser combatido em um processo em que se ampliaram iniciativas de militarização no enfrentamento as drogas, principalmente em solo latino-americano.

A atuação de órgãos brasileiros e a evolução da legislação do país, no tocante ao tráfico de drogas, somente se concretizaria com a Lei 6.368 de 1976 (Lei de Tóxicos). Durante a década de 1970, o papel do Brasil na dinâmica internacional do tráfico de drogas ilícitas começou a alterar-se. Sendo vizinho de países produtores de drogas como Bolívia, Peru e Colômbia, o Brasil ainda figurava como rota do fluxo internacional e como discreto centro consumidor de drogas (Rodrigues, 2003). O consumo de maconha entre jovens da classe média e a chegada da cocaína ao mercado de drogas, são marcos do período, tendo consolidado suas estruturas durante os anos 1980 (Fraga, 2003). Observa-se o crescimento das atividades do comércio de drogas nos grandes centros urbanos brasileiros. Dominadas por chefes do jogo do bicho, essas atividades seriam noticiadas amplamente pelos veículos de comunicação. A lógica de divulgação das notícias que até aquele momento priorizava a pauta internacional passa a traçar rotas e conexões entre o contexto social brasileiro e estrangeiro.

Nos anos de 1990 as atividades organizadas do tráfico de drogas no Brasil, foram ganhando amplitude, estendendo o seu poder de atração sobre os jovens pobres, em idade cada vez mais tenra (Zaluar, 1994b). Em sua maioria, o tráfico mobiliza jovens que são inseridos numa lógica de trabalho informal (Zaluar, 1994b), dotada de regras e obrigações de retorno e controle imediato que forjam um contrato social violento e implacável (Feffermann, 2006). As práticas de violência exercidas nas lógicas de transação do tráfico de drogas, e também àquela exercida pelo Estado em seu combate, passam a ser naturalizadas, como forma autorizada de enfrentamento daqueles factualmente envolvidos com as atividades ilícitas ou potencialmente ofensivos (Chauí, 1980; Coimbra, 2001a, 2001b).

No âmbito jurídico, a Lei 11.343, de 23 de agosto de 2006, a nova Lei de Tóxicos, trouxe algumas novidades em relação à antiga legislação de 1976. A mesma institui o 
Sistema Nacional de Políticas Públicas sobre Drogas, e assim, mantém a política de repressão ao tráfico, mas passa a dar maior atenção para o tratamento dos toxicômanos, identificando sua rede de apoio e diretrizes (Araújo, 2012).

Internacionalmente, os EUA permanecem tendo destaque no comando de medidas de controle e combate das drogas, militarizando iniciativas principalmente na Colômbia, mas também nas fronteiras de outros países como o Brasil, levando a discussões sobre a soberania dos países de região amazônica. O Brasil mantém um papel importante como rota para o escoamento da produção de drogas na América do Sul, mas agora se preocupa, também, com o combate armado aos traficantes e às classes perigosas, desenvolvendo desde a década de 1990 intervenções das forças armadas em regiões sob o "domínio" do crime organizado (Coimbra, 2001b). Desta forma, a violência é legitimada como forma de controle do Estado pela força (Chauí, 1980), em operações de "guerra" amplamente divulgadas pela mídia.

\section{Comunicação de massa e representações sociais}

As informações documentais provenientes de um veículo de mídia impressa de grande difusão, a revista Veja, constituíram as fontes de dados desta pesquisa. Desta forma, pretende-se lidar com um campo fértil de construção de representações sociais, uma vez que, os órgãos de imprensa são "ao mesmo tempo receptores, processadores e transmissores da informação" (Menandro, Trindade \& Almeida, 2010, p. 65), configurandose como importantes atores nos processos de comunicação social que se desenvolvem em nossa sociedade.

Desde o estudo inaugural de Moscovici (2012), publicado originalmente em 1961, os processos de comunicação que atuam na construção e organização de RS, vêm sendo investigados a partir da análise de material jornalístico. Os materiais de mídia impressa representam importante recurso de pesquisa no campo das representações sociais, possibilitando o acesso a universos lexicais e redes de significados presentes em períodos históricos anteriores aos vivenciados. De forma ampla, "Os processos de comunicação são a gênese das representações sociais. Estas são desenhadas na comunicação interpessoal, intergrupal e na comunicação social; são criadas para comunicar e no ato de comunicar" (Ordaz \& Vala, 2000, p. 111).

Os processos de comunicação são vistos por Jovchelovitch (2000) como mediadores entre realidades múltiplas, entre indivíduos com necessidades diversas e o mundo. Quando estas mediações ocorrem surgem representações sociais, e então acabam por se tornar, também mediadoras, pois reapresentam objetos sociais nos diálogos cotidianos, facilitando o contato entre os grupos e indivíduos, negociando e construindo conjuntamente a realidade social, uma vez que "o sujeito é condenado a buscar mediações. Outro, palavra e ação constituem - em delicada e intricada trama - estas mediações: com elas tentamos acalmar as lacunas que constituem o que somos" (Jovchelovitch, 2000, p. 183).

Os meios de comunicação de massa ampliam a dimensão destas mediações, na medida em que os veículos de mídia aproximam de forma invisível os sujeitos que compõe seu público, uma vez que:

... a mídia penetra cada lar e procura cada indivíduo para torná-lo membro de uma massa... É um tipo de massa, entretanto, que não se vê em lugar algum precisamente porque ela está em todo lugar. As milhares de pessoas que silenciosamente lêem seus jornais e involuntariamente falam como o rádio são membros de uma nova forma de multidão, que é imaterial, dispersa e 
doméstica... Eles estão cada um em suas casas, mas estão juntos, e parecem ser diferentes, mas são iguais... (Moscovici, como citado em Jovchelovitch, 2000, p. 86)

O argumento de Moscovici (como citado em Jovchelovitch, 2000) facilita o resgate da dimensão de grupo, possível nos estudos documentais com material jornalístico, uma vez que o "jornal se torna um indicador desta visão de mundo" (Bauer, Gaskell \& Allum, 2008, p. 22) compartilhada por leitores e produtores das reportagens.

A mídia enquanto meio institucionalizado de comunicação é responsável tanto pelo conteúdo apresentado ao grande público quando pela forma como a informação será difundida à população. Desta forma, são produzidas mudanças nas vivências do espaço e do tempo dos indivíduos que terão novos parâmetros para sua orientação, podendo aproximarse ou distanciar-se de realidades antes desconhecidas,

\begin{abstract}
... os meios de comunicação se tornaram constitutivos da vida social. Eles alteraram modos de interação, transformaram o acesso a, e o consumo de bens simbólicos, re-estruturaram a política institucional e como não poderia deixar de ser eles mudaram radicalmente as fronteiras entre a esfera pública e privada (Jovchelovitch, 2000, p. 89).
\end{abstract}

Neste sentido, cabe mencionar como defendido por Jovchelovitch (2000), que nosso estudo não é um estudo sobre a mídia no Brasil, nem tão pouco, uma análise dos "processos específicos na linguagem da mídia, que permitem o surgimento de representações sociais" (p. 92), buscaremos apenas o mapeamento de representações sociais de um objeto social específico que são difundidas e produzidas nestes veículos.

Entre os produtores das informações, durante grande parte do período histórico da pesquisa, exigiam-se dos profissionais jornalistas a diplomação de nível superior ${ }^{7}$, nas antigas redações dos jornais brasileiros ainda contavam com fotógrafos e outros profissionais de baixo nível socioeconômico e que em muitos casos vivenciavam a realidade das classes desfavorecidas. Segundo Ramos e Paiva (2007) aos poucos a classe jornalística foi se tornando majoritariamente composta por pessoas de classe média, produzindo um olhar externo ou estrangeiro na leitura da realidade das classes baixas.

Em suas pesquisas realizadas na década de 1980, Zaluar (1994a) observa que para os veículos de comunicação e para a população em geral os morros cariocas eram considerados como "antro de perigosos criminosos, assassinos em potencial, traficantes de tóxicos, etc." (Zaluar, 1994a, p. 10). A autora identifica, inclusive, dificuldades em sua entrada no campo de investigação, devido à associação feita pela população, entre seu trabalho e o de uma jornalista. Naquele momento, a população encontrava-se indignada com a mídia que danificava ainda mais a imagem das favelas e de sua população que era apresentada como integralmente criminosa.

Na mesma direção, a pesquisa realizada por Cruz Neto, Moreira e Sucena (2001), no início da década de 1990, aponta que grande parte das matérias jornalísticas sobre o tráfico de drogas da época apresentam narrativas que fomentam atitudes de discriminação com determinados extratos da população, criando um perfil estigmatizante de seus protagonistas: "compromissados com o reduzido espaço e a necessidade de vender exemplares, proprietários, editores e repórteres ... acham plausível expressar aquelas que

\footnotetext{
7 Em 2009 o Supremo Tribunal Federal decidiu pela não exigência de diploma em Jornalismo para o exercício da profissão, alegando que a exigência feria o princípio da liberdade de expressão. Em 2012, novamente a matéria voltou a ser problematizada, sendo aprovada no Senado a Proposta de Emenda Constitucional (PEC) que retomaria a exigência do diploma, a PEC ainda tramita na Câmara dos Deputados.
} 
julgam ser as principais características dos jovens em uma página com gráficos, ou mesmo conformá-las em um box ..." (Cruz Neto, Moreira \& Sucena, 2001, p. 84).

Coimbra (2001b) também destaca o papel da mídia de massa na construção das ideias sobre a criminalidade na história recente do país, favorecendo a criação de estereótipos e processos de segregação em relação às classes subalternas, uma vez que as narrativas difundidas "produzem poderosos e eficientes processos de subjetivação; forjam existências, vidas, bandidos e mocinhos, heróis e vilões" (p. 37).

Estes relatos de pesquisa remetem a uma das dimensões que pretendemos acessar, ou seja, o papel da mídia na formação de representações sociais para o fenômeno do tráfico de drogas. Os vieses apresentados pelas informações divulgadas pela mídia revelam condições que perpassam este trabalho de pesquisa: se por um lado contamos com rica fonte documental para acessar o tema, por outro, este material é influenciado por aspectos ideológicos, editoriais e políticos (Souza \& Menandro, 2007; Ordaz \& Vala, 2000), ainda pouco discutidos.

Neste sentido, como destacado por Noto e Galduróz (1999), a divulgação com pretensão científica produzida pela mídia acaba, por vezes, prejudicando o acesso da população em geral às pesquisas sobre as drogas no Brasil, uma vez que, "a maioria da população tem a mídia como principal fonte de informações, o que é divulgado pelos meios de comunicação de massa passa a ser padrão de verdade" (p. 147), consolidando-se estereótipos, atitudes e opiniões (Jodelet, 2001). Deste modo, conhecer os atravessamentos culturais, sociais, econômicos e históricos que incidem na produção dos textos jornalísticos é condição básica para a uma leitura analítica dos fatos narrados.

\section{Método}

Esta pesquisa propõe uma investigação de caráter exploratório e documental, utilizando registros textuais de uma revista de circulação nacional. Os dados que integram o corpus $^{8}$ desta pesquisa provêm de matérias, fragmentos de matérias e comentários, publicados pela revista Veja entre os anos de 1968 e 2010, e que tratavam do assunto tráfico de drogas.

Souza e Menandro (2007) destacam que a pesquisa documental é via privilegiada de conhecimento dos acontecimentos históricos, atuando como uma verdadeira "máquina do tempo" (p. 152) ao transportar o pesquisador aos mais inusitados cenários. Ainda assim, o cenário sócio-político influencia a configuração dos materiais documentais e, portanto, os textos selecionados para compor este estudo são carregados por estas marcas. A produção documental, e neste caso jornalística, não apenas registra os fatos vivenciados, mas reproduz formas de pensar em um tempo e espaço específicos. Como indicado por Olson (1997), ao cunhar a metáfora do "mundo de papel", o conjunto de documentos produzidos por uma sociedade em determinado tempo se relaciona com as representações dos grupos sobre os objetos sociais, ou seja, compõe algo mais do que uma reprodução dos acontecimentos, são atos de intenção e interpretação.

Neste sentido, os saberes em circulação na produção e difusão do semanário, apresentam representações sociais elaboradas em meio a um grupo social específico,

\footnotetext{
${ }^{8}$ Do latim, corpo. Nas pesquisas históricas ou sociais trata-se da coleção homogenia de textos sobre determinado tema, utilizada quando o tema investigado possui grande variabilidade e inviabiliza os critérios de amostragem representativa (Bauer \& Aarts, 2002).
} 
leitores das classes A e B, majoritariamente do sexo masculino de faixas etárias economicamente ativas (de 20 a 49 anos) e em sua maioria moradores da região sudeste do Brasil (Grupo Abril, 2011). Trata-se de um grupo social que atinge maiores graus de instrução e renda, sendo considerado socialmente como formador de opinião, produtor e detentor de conhecimento. Este estudo indica uma via de acesso a ideias largamente difundidas e fortemente valorizadas por estarem atreladas a posicionamentos de uma classe dominante em nossa sociedade.

A seleção e coleta das matérias jornalísticas foram realizadas no site do acervo digital da revista $V_{e j a}{ }^{9}$. Utilizou-se uma ferramenta presente no site, para buscas avançadas "com a expressão exata", a partir dos termos: tráfico, traficante e narcotráfico. Devido ao grande volume de publicações, do total de exemplares da revista que citavam o tema, a cada mês foi incluída uma matéria no corpus, sendo estimado o máximo de doze matérias por ano. Ainda que a escolha dos termos-chave, tenha sido eficaz, o conjunto das matérias selecionadas eletronicamente foi depurado, a partir de uma leitura na íntegra das matérias, de maneira a separar aquelas que realmente tratavam do tema em questão. Foram desconsideradas ocorrências que se referiam a outros tipos de tráfico, tais como: tráfico de influência, de pessoas, de animais, dentre outros. Também foram desconsideradas as ocorrências em que a palavra tráfico ou traficante era usada sem um qualificador ("de drogas", "de heroína" etc.) e seu sentido não ficava explícito por informações contextuais. Matérias que apenas citavam o tráfico de drogas (por exemplo, em uma lista de outros crimes), sem desenvolver nenhuma ideia vinculada ao termo, foram descartadas, assim como as mensagens publicitárias e as cartas de leitores.

O controle do material selecionado se deu a partir do registro em uma ficha de organização, composta das seguintes variáveis: Edição; Ano; Década; Data; Termo de busca; Observações da leitura preliminar; Conteúdo (utilização de trecho ou íntegra da matéria); Sexo do envolvido; Ator (caracterização da pessoa envolvida com o tráfico de drogas); Local (Nacional, Internacional e Fronteira), Matéria de Capa. Essas informações foram transformadas em um banco de dados de controle em formato Excel. Cada matéria selecionada foi salva, inicialmente, em formato PDF (Portable Document Format), e em seguida, foram convertidas em textos editáveis de modo a serem submetidas à análise.

Após tratamento do corpus, este foi submetido à análise lexical ou estatística textual desenvolvida com o auxílio do software ALCESTE (Análise Lexical por Contexto de um Conjunto de Segmentos de Texto), produzido em 1979, por Max Reinert. A conciliação de diversas análises estatísticas faz com que o programa seja considerado não somente uma técnica, mas também uma metodologia de exploração e descrição de dados (Kronberguer \& Wagner, 2008). Ao utilizar as dimensões quantitativa e qualitativa, as estratégias do programa conseguem indicar conjuntos textuais que se referem a um determinado contexto e reproduzem, a partir do discurso, estruturas simbólicas que organizam práticas sociais.

\section{Resultados e discussão}

O total de itens incluídos no corpus para análise foi de 321 matérias ou fragmentos de matérias, sendo o primeiro destes registros datado de 1 o de janeiro de 1969. Apesar de a investigação ter incluído o ano de 1968, não foi encontrado exemplar nesse ano, o período foi mantido na discussão proposta, por trazer importantes contornos para a compreensão

\footnotetext{
${ }^{9}$ Endereço do site: <http://acervoveja.digitalpages.com.br/home.aspx>
} 
do fenômeno no país em função das condições políticas e sociais impostas pelo regime militar.

Neste recorte apresentaremos alguns resultados do procedimento de Classificação Hierárquica Descendente, presente no ALCESTE. Este procedimento baseia-se no princípio da maior homogeneidade interna à classe e da maior diferenciação possível entre as classes. Esta classificação ocorre mediante sucessivas comparações realizadas pelo programa, entre as Unidades de Contexto Elementar identificadas e as formas reduzidas das palavras plenas (substantivos, verbos, adjetivos e advérbios). 0 critério para a divisão é o qui-quadrado $\left(\mathrm{x}^{2}\right)$ das palavras reduzidas, ou seja, a distribuição média de uma palavra é comparada com a distribuição na classe, a fim de identificar vocabulários diferenciados no discurso (Kronberguer \& Wagner, 2008; Oliveira, Gomes \& Marques, 2005; Menandro, Trindade \& Almeida, 2010; Pedrosa, 2012).

O dendrograma resultante deste procedimento apresentou sete classes de palavras, organizadas em dois grandes grupos que se opõem e se complementam. A nomeação das classes (Figura 1) partiu do conceito de mundo lexical destacado por De Alba (2004), que permite $o$ resgate da dimensão das ancoragens e objetivações cruciais para compreendermos as RS. A dimensão dos mundos lexicais se encontra entranhada nas experiências individuais dos sujeitos, e também nas formas de conhecimento tradicionais e científicas presentes em uma sociedade. As sete classes apontadas na análise do corpus desta pesquisa revelaram conteúdos lexicais significativos que remetem as negociações entre a esfera científica e do senso comum na construção da realidade social ao longo do período histórico. A nomeação das classes ocorreu após procedimentos de leitura das palavras, das variáveis, e das Unidades de contexto elementar (afirmativas do texto, dimensionadas em função do tamanho total do corpus) associadas à classe. Além disso, a interpretação do conteúdo das classes e das relações apontadas pelas análises estatísticas, foram desenvolvidas a partir do conhecimento prévio das pesquisadoras sobre o campo empírico e teórico acerca do objeto.

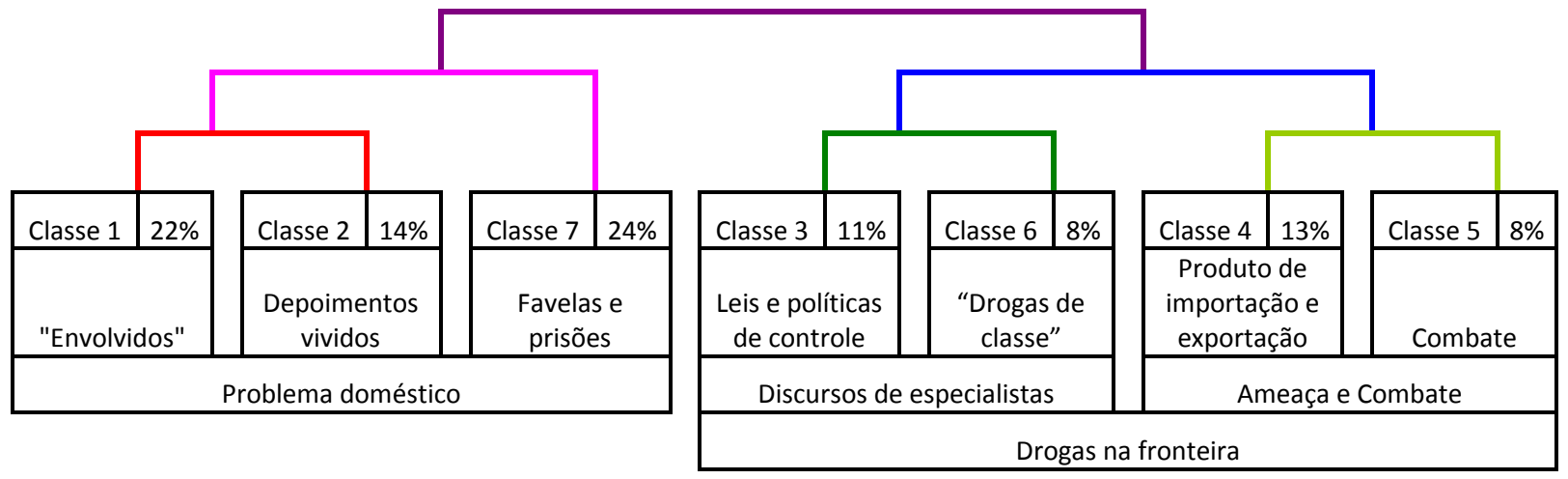

Figura 1 - Dendrograma de Classificação Hierárquica Descendente, Revista Veja (1969-2010)

A Classe 3 (Leis e políticas de controle) articula-se em torno de temas que incluem aspectos legais, econômicos e políticos do tráfico de drogas, ou mais precisamente, sobre o controle das drogas. A UCE abaixo está entre as que apresentam maior medida de quiquadrado $\left(\chi^{2}=34\right)$ e também ilustra ao léxico referente a classe. Cabe ressaltar que as palavras antecedidas pelo sinal gráfico \# são aquelas que o programa selecionou como possuindo alguma associação com a classe, já as palavras em negrito, são as que possuem os maiores valores de qui-quadrado. 
\#mas \#esses grupos delinquentes, \#como pcc, \#farc e paramilitares da colombia, \#vivem do narcotrafico. e, enquanto o narcotrafico estiver aumentando, e \#esta. e dificil \#dizer que eles \#nao voltarao a \#agir. \#erros e acertos brasileiros o brasil, \#assim \#como \#outros \#paises, erra no combate a \#criminalidade por dissociar as \#politicas \#social e repressiva.

A Classe 6 ("Drogas de classe") trata do uso e da dependência de drogas, que ameaçam um público específico, pessoas que economicamente podem consumir estas substâncias. Os textos apresentam entrevistas e opiniões de especialistas sobre o uso de substâncias, formando um conjunto de saberes médicos-científicos que servem para nortear posicionamentos práticos em relação às drogas. A UCE abaixo $\left(\chi^{2}=42\right)$ exemplifica seu conteúdo lexical.

\#ecstasy \#mata \#especialista em \#dependencia diz que e tolice acreditar que \#drogas \#sinteticas sejam menos letais veja _ qual sua opiniao sobre a legalizacao do \#maconha? levounis _ a legalizacao \#pode ate reduzir o \#numero de crimes associados ao \#uso e ao trafico de \#drogas mas esse e so um \#aspecto dentro de uma sociedade em que a \#dependencia e um problema de \#grande extensao.

O conjunto das classes 3 e 6 recebeu o nome "Discursos de especialistas", pois apresenta o discurso político e técnico-científico como forma de balizar a relação do indivíduo comum com as drogas.

Já na Classe 4 (Produto de importação e exportação) nota-se a presença de elementos relacionados às transações e etapas incluídas no tráfico de drogas internacional, desde a produção, o transporte e a apreensão das drogas, com destaque para a cocaína.

3_a \#cocaina a colombia, embora \#pequena \#produtora de \#coca, \#fabrica com a \#pasta contrabandeada do \#peru e da \#bolivia mais de 40 \#por_cento da \#cocaina comercializada ilegalmente \#no mundo.

O conteúdo da Classe 5 (Combate) estrutura-se de forma complementar ao mundo lexical expresso na classe 4, pois se contrapõe a lógica da produção das drogas, revelando o discurso daqueles que tentam se proteger contra a invasão de um inimigo clandestino, o tráfico de drogas.

dentro de um pacote \#antidrogas em preparacao pelo \#governo \#americano, que envolvera \#recursos de 8 \#bilhoes de \#dolares. nos \#proximos meses, entre cinquenta e 100 assessores \#militares \#americanos deverao desembarcar na \#colombia para treinar policiais e \#militares no \#combate \#ao \#trafico.

O agrupamento das classes 4 e 5, denomina-se "Ameaça e combate", pois as classes apresentam os principais países do circuito internacional do tráfico, muitos onde o sistema econômico formal depende dos lucros das drogas, e onde os EUA atuam amplamente para inibir as transações ilegais do tráfico (plantio, refino, exportação das drogas etc.). Os elementos trazidos por este universo semântico referem-se a um problema externo ao grupo de referência (aquele que emite a mensagem), ou seja, tratam de um problema sobre o qual a classe com maior poder aquisitivo ou o grupo de países desenvolvidos, propõem sua análise e intervenção. Os problemas do consumo e da economia do tráfico, são apontados nas classes 6 e 4, problemas que devem ser combatidos (Classe 5), e frente ao qual a figura do especialista é convidada a opinar (Classe 3). O conjunto das quatro classes foi nomeado por "Drogas na fronteira". 


\begin{tabular}{|c|c|c|c|c|c|c|c|}
\hline Classe 3 & $11 \%$ & Classe 6 & $8 \%$ & Classe 4 & $13 \%$ & Classe 5 & $8 \%$ \\
\hline Variáveis $^{1}$ & $\chi^{2}$ & Variáveis & $\chi^{2}$ & Variáveis & $\chi^{2}$ & Variáveis & $\chi^{2}$ \\
\hline $\begin{array}{l}\text { *ator_19 } \\
\text { *sex_4 } \\
\text { *ed_1811 } \\
\text { *ano_2003 }\end{array}$ & $\begin{array}{l}400.0 \\
319.6 \\
191.6 \\
186.2 \\
\end{array}$ & $\begin{array}{l}\text { *ed_82 } \\
\text { *ano_1970 } \\
\text { *ed_1669 } \\
\text { *ator_19 }\end{array}$ & $\begin{array}{l}432.3 \\
426.0 \\
202.1 \\
199.9\end{array}$ & $\begin{array}{l}\text { *loc_3 } \\
\text { *ed_967 } \\
\text { *ano_1980 } \\
\text { *ed_631 }\end{array}$ & $\begin{array}{l}425.3 \\
222.7 \\
219.9 \\
205.8 \\
\end{array}$ & $\begin{array}{l}\text { *loc_2 } \\
\text { *ator_3 } \\
\text { *ed_737 } \\
\text { *ed_1113 }\end{array}$ & $\begin{array}{l}510.7 \\
224.0 \\
211.7 \\
102.5\end{array}$ \\
\hline Formas ${ }^{2}$ & $\chi^{2}$ & Formas & $\chi^{2}$ & Formas & $\chi^{2}$ & Formas & $\chi^{2}$ \\
\hline $\begin{array}{l}\text { senhor+ } \\
\text { nosso+ } \\
\text { Não } \\
\text { Isso } \\
\text { Interpol } \\
\text { farc+ } \\
\text { acha+ } \\
\text { Países } \\
\text { conselho+ } \\
\text { problem< }\end{array}$ & $\begin{array}{l}112.1 \\
104.4 \\
100.3 \\
90.2 \\
84.6 \\
81.7 \\
80.0 \\
73.5 \\
72.9 \\
72.7\end{array}$ & $\begin{array}{l}\text { LSD } \\
\text { efeito+ } \\
\text { Uso } \\
\text { substanci+ } \\
\text { dose+ } \\
\text { dependencia+ } \\
\text { Heroína } \\
\text { pesquisa+ } \\
\text { Ecstasy } \\
\text { droga+ }\end{array}$ & $\begin{array}{l}309.2 \\
229.5 \\
181.7 \\
163.9 \\
144.8 \\
129.9 \\
125.2 \\
121.7 \\
119.7 \\
116.5\end{array}$ & $\begin{array}{l}\text { Cocaína } \\
\text { quilo+ } \\
\text { policia_federal } \\
\text { AM } \\
\text { pan+ } \\
\text { Bolívia } \\
\text { Éter } \\
\text { aeroporto+ } \\
\text { Pasta } \\
\text { coc+ }\end{array}$ & $\begin{array}{l}384.3 \\
331.0 \\
199.2 \\
147.5 \\
147.5 \\
145.4 \\
137.8 \\
129.6 \\
117.4 \\
116.2 \\
\end{array}$ & $\begin{array}{l}\text { america< } \\
\text { colombia } \\
\text { estados_unidos } \\
\text { noriega } \\
\text { governo+ } \\
\text { eua } \\
\text { dolar+ } \\
\text { genera+l } \\
\text { combat+ } \\
\text { arce_gomez }\end{array}$ & $\begin{array}{l}413.8 \\
195.3 \\
185.0 \\
169.4 \\
164.4 \\
161.5 \\
152.0 \\
150.8 \\
132.2 \\
125.0\end{array}$ \\
\hline \multicolumn{2}{|c|}{ Leis e políticas de controle } & \multicolumn{2}{|c|}{ "Drogas de classe" } & \multicolumn{2}{|c|}{$\begin{array}{c}\text { Produto de importação e } \\
\text { exportação }\end{array}$} & \multicolumn{2}{|c|}{ Combate } \\
\hline \multicolumn{4}{|c|}{ Discursos de especialistas } & \multicolumn{4}{|c|}{ Ameaça e Combate } \\
\hline \multicolumn{8}{|c|}{ Drogas na fronteira } \\
\hline
\end{tabular}

Notas: 1. Descrição das variáveis - ator: envolvido; sex: sexo do envolvido; Ed: edição da revista; ano: ano de publicação; loc: local descrito. 2. As formas apresentadas correspondem às palavras plenas com maior qui-quadrado.

Figura 2 - Conjunto de classes "Drogas na Fronteira" no Dendrograma de Classificação Hierárquica Descendente, Revista Veja (1969-2010)

A discussão suscitada pelas "Drogas na Fronteira" revela tensões entre diversos grupos sociais frente ao tráfico de drogas. Assim, não somente os americanos buscariam formas de lidar com o problema, o mesmo se daria no contexto nacional a partir da ativação tanto de elementos compartilhados, como de novos itens para a composição da representação social. Deste modo, estas classes contêm elementos sobre as relações internacionais do comércio e combate às drogas, mas também sobre o contato de grupos sociais brasileiros (principalmente atores da classe média, médicos e estudantes) com este fenômeno. O conjunto de classes revela como as conversações em torno do combate das drogas acercam-se do discurso científico, encontrando justificativas sobre os malefícios do uso, do comércio e das relações sociais implicadas no tráfico.

Como os processos de comparação e diferenciação social (Tajfel, 1983) se desenvolvem no contato entre determinados grupos, em tempos e espaço peculiares, na sociedade brasileira estes levaram a definição de grupos sociais específicos como responsáveis pela disseminação e pelos riscos ocasionados pelo tráfico de drogas. Esse conjunto lexical remete à dinâmica social presente na sociedade americana, sem descolá-la da realidade brasileira, e busca aproximar o leitor de um cenário novo e ameaçador. É no cenário estrangeiro que as notícias da época encontraram elementos representacionais para ancorar explicações para o fenômeno das drogas e seu comércio no Brasil, de maneira que são os estrangeiros os primeiros a trazer as drogas para o país, tanto em nível literal como simbólico.

À vista disto, conhecer o panorama americano se fez necessário, porque este se impõe de forma marcante nos textos analisados, que se configuram a partir do diálogo com a pauta internacional de notícias, e desta forma, a apreensão destes contornos ajuda-nos a compreender os mecanismos pelos quais a sociedade brasileira pôde elaborar um novo fenômeno. A diferenciação dos territórios interno e externo se deu de forma a organizar a interpretação dos dados que compõe o campo representacional, não tendo sido planejada 
anteriormente. A construção seletiva e a focalização de determinados elementos que circulam nas conversações do senso comum fazem parte do processo de construção das RS e são nítidos na análise do conjunto lexical presente no corpus. A pauta internacional apresentada pela revista contribuiu para o reforçamento de ideias de distância e proteção em relação à ameaça (drogas/tráfico). Além disso, a construção de narrativas sobre a aproximação e/ou a invasão de nossas fronteiras, fomenta novas negociações simbólicas acerca do objeto social.

A sociedade americana condensou sob os efeitos nocivos causados pelas drogas (desde o álcool às drogas sintéticas) a ameaça à produção e ao lucro capitalistas, que seria mensurada a partir do desempenho dos jovens, estes últimos, o grupo social a quem se associava o uso da droga no período. Preceitos religiosos e a tradição econômica liberal levaram ao expurgo dos comportamentos de uso e abuso das drogas.

Com as perdas americanas em decorrência da Guerra do Vietnã (1955-1975), o governo precisou encontrar uma forma de restabelecer o orgulho nacional (Araújo, 2012), reaquecer o mercado, incentivar a economia e buscar o apoio popular. É neste contexto, que durante um pronunciamento no ano de 1972, o presidente Richard Nixon (1969-1974) identifica um novo inimigo do Estado americano ao declarar "os psicoativos ilícitos como inimigos no 1 da América e, em consequência declara guerra às drogas" (Rodrigues, 2003, p. 42, grifos do autor). O Estado buscava um novo inimigo que externalizasse sua instabilidade (Feffermann, 2006) e ao destacar a existência de países produtores e consumidores de drogas, os EUA exteriorizam seus inimigos, países (asiáticos e latino-americanos) disseminadores de drogas,

\footnotetext{
... a terminologia classificatória "país produtor de droga/país consumidor de droga", cunhada ainda no governo do republicano Richard Nixon, nos anos setenta, é de extrema eficácia. Um país seria, assim, responsabilizado pela produção do "mal", enquanto outro, vitimizado pela afronta exógena, teria o direito de se defender atacando a "fonte" (Rodrigues, 2002, p. 68).
}

O movimento de identificação dos grupos sociais inimigos pode ser compreendido como um primeiro esforço de objetivação (nomeação e materialização), para um fenômeno que ameaçava a sociedade americana e precisava encontrar uma face, a fim de abandonar a dimensão de um inimigo abstratamente disseminado. Neste sentido, "objetivar significa resolver o excesso de significações pela materialização (e assim guardar distância em relação a elas). Também significa transplantar, no plano da observação, o que era só inferência ou símbolo" (Moscovici, 2012, p. 101).

Em nossa análise, os países chamados na época de subdesenvolvidos, que eram dependentes economicamente do mercado americano, como Peru, Panamá, Bolívia, Colômbia e México, e em alguns momentos o próprio Brasil, tornaram-se lugares intensamente associados à produção e distribuição de drogas, legítimos representantes dos "subúrbios" do globo. Estes lugares passam a ser símbolos da produção e disseminação das drogas, sendo integralmente responsabilizados por estas.

Em todo o processo notamos a tendência dos grupos sociais à valorização dos atributos do grupo próprio (endogrupo) em detrimento do grupo de fora (exogrupo), esta tendência pode ser percebida pela análise dos processos de categorização e diferenciação grupal que organizam as relações de pertencimento dos indivíduos aos grupos, determinantes para a composição da identidade social (Tajfel, 1982, 1983). A compreensão da influência das relações identitárias na composição das RS, e também, da recíproca participação das RS na composição das identidades, mostrou-se crucial no exercício de discussão dos dados desta pesquisa, desta forma, enfatizamos que: 
Os grupos desenvolvem formas específicas de produção de significados, ou seja, cada grupo social, dependendo da sua inserção no todo social, de suas relações com outros grupos, desenvolve formas específicas de estruturar suas representações sociais. Cada grupo social tem sua forma específica de representação de mundo. Isto significa que podem ser estabelecidas clivagens entre os grupos sociais segundo as suas representações. Indivíduos e grupos expressam sua identidade através de suas representações (Andrade, 2000, p. 144, grifos do autor).

Entre os americanos, o mal das drogas foi relegado a grupos estrangeiros, fato que parece ocorrer diferentemente no Brasil. Em nossa sociedade, os processos de exclusão social se processariam por outros mecanismos, elegendo grupos internos como os principais depositários dos malefícios produzidos pelas drogas. Desta forma, repete-se uma lógica binária de leitura da realidade, antes observada entre americanos e estrangeiros, e agora em território brasileiro, entre classes dominantes e classes subalternas.

Se o tráfico de drogas é o catalisador do perigo potencial das drogas, seus mensageiros são grupos específicos, repetindo-se uma visão dicotômica já observada no âmbito internacional da questão. No Brasil encontram-se de um lado, os pobres, negros e traficantes; e de outro, os ricos, brancos e consumidores. Segundo Chauí (1980) nossa sociedade está acostumada a empregar mecanismos ideológicos que invisibilizam diferenças sociais impregnadas de preconceitos de classe/raça, mascarados por uma aparência de unidade social. Desta forma, o pobre (malandro, ladrão, marginal, sujo etc.) carrega a culpa e a responsabilidade pelas mazelas sociais que acometem a classe média, constituindo uma categoria segregada, mas integrada e funcional para a dinâmica social (Souza, 2004; Sawaia, 2008). Assim, as políticas públicas acabam por voltar-se contra os pobres, potencialmente ou diretamente, vinculados ao tráfico e aos traficantes de drogas, sob os quais as práticas violentas de coação são autorizadas em nome da ordem social (Chauí, 1980; Coimbra, 2001b). Tais atores e contextos são, portanto, içados pelo léxico apresentado no segundo conjunto de classes revelado no procedimento de Classificação Hierárquica Descendente.

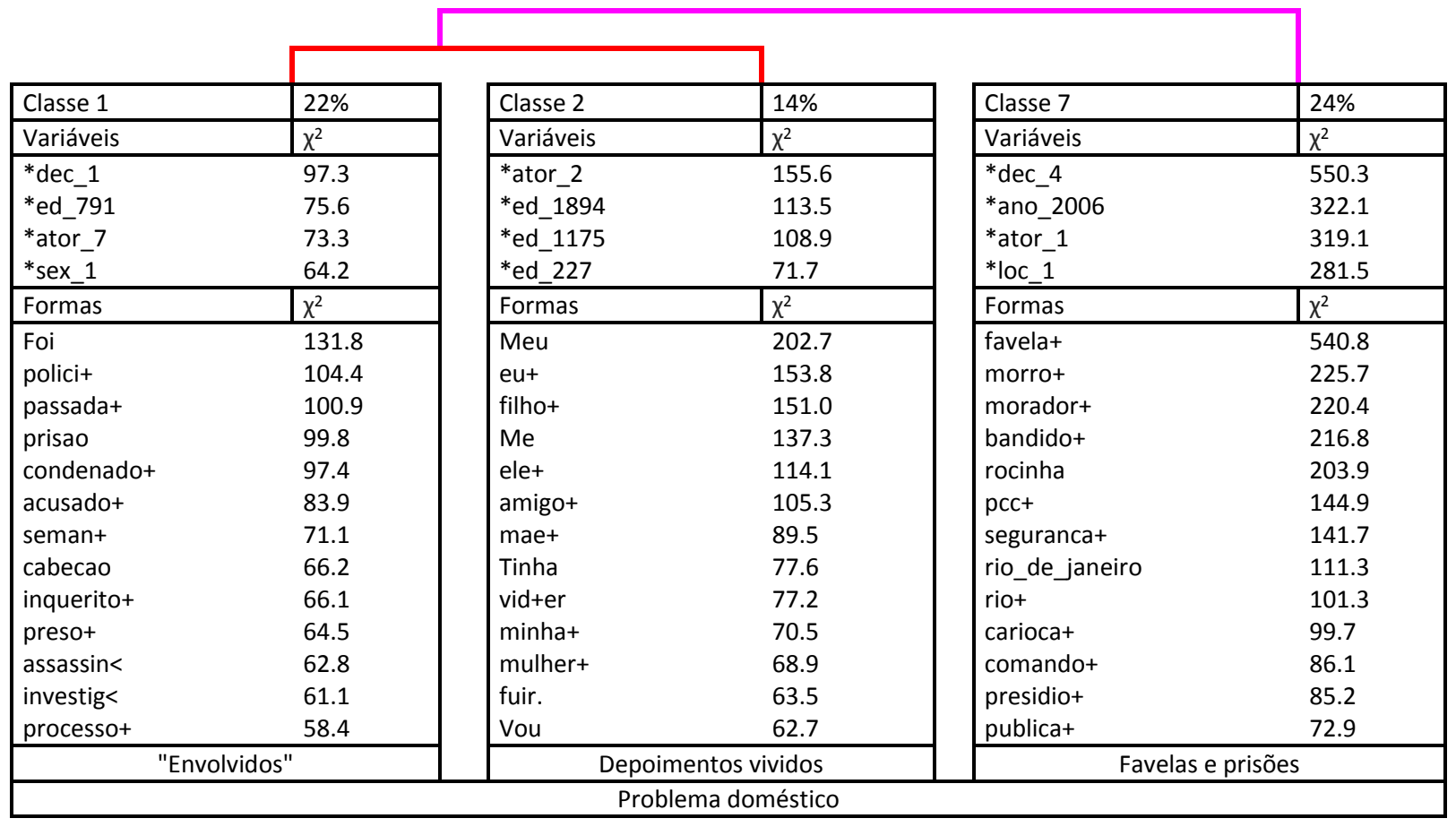

Figura 3 - Conjunto de classes "Problema doméstico" no Dendrograma de Classificação Hierárquica Descendente, Revista Veja (1969-2010) 
O segundo grupo de classes é composto da Classe 1 ("Envolvidos") que menciona atores que mantêm relações com o tráfico (de policiais a bandidos), participando de sua lógica de funcionamento e condenação judicial; enquanto a Classe 2 (Depoimentos vividos) revela falas de pessoas que conviveram com o tráfico de drogas em uma dimensão social próxima ou familiar; e, por fim, a Classe 7 (Favelas e prisões) refere-se a lugares ou locais associados ao tráfico de drogas, intimamente relacionados às esferas cotidianas onde viveram os envolvidos e seus entes apresentados nas classes 1 e 2. Com o maior quiquadrado entre todas as palavras plenas analisadas neste estudo, o termo favela $\left(x^{2}=540,34\right)$ revela o principal contexto brasileiro onde o tráfico se estabelece. As três classes apresentam elementos do contexto brasileiro do tráfico de drogas, e mais do que isso, revelam uma lógica interna de organização do fenômeno, apresentando os atores envolvidos no passado e no presente, assim como as narrativas daqueles que sofreram pessoalmente os impactos da realidade do tráfico. As classes apresentam aspectos opostos e complementares sobre uma mesma realidade, que acessa a dimensão das pessoas que vivem ou convivem com a realidade do tráfico no Brasil, por isso este agrupamento foi denominado "Problema doméstico".

A seguir serão apresentadas algumas das principais UCEs associadas as classes, os trechos são precedidos de seus respectivos valores de qui-quadrado.

Classe $1\left(\chi^{2}=27\right)$ juntamente com dois \#policiais que o ajudavam \#na tarefa de roubar eletrodomesticos. \#durante \#sete \#horas da \#ultima \#sexta_feira, \#porem, \#vianinha e outros implicados _ \#oito \#policiais, dois ex_militares e dois assaltantes \#acusados de crimes de \#morte _ nao \#foram a \#julgamento.

Classe $2\left(\chi^{2}=48\right)$ nao \#fez a sua parte. \#agora e a hora de \#fazer a \#coisa \#certa. nessa quebrada \#sempre foi \#tudo lindo e \#elegante, nao e \#agora que \#vai \#ficar quadrado, \#certo, meus irmaos? \#entao e o \#seguinte, esse salve e prioridade e o irmao que nao acatar \#vai \#ser cobrado a \#altura.

Classe $7\left(\chi^{2}=36\right)$ a reuniao do \#bando durou o dia inteiro. a policia nao apareceu. o reino dividido \#dos robin_hood \#cariocas a solidariedade \#dos \#moradores do \#morro do juramento ao \#traficante escadinha e apenas uma amostra \#das aliancas entre os reis do \#crime no \#rio e \#parte \#dos \#habitantes \#das 410 \#favelas da \#cidade.

O "Problema doméstico" do tráfico de drogas no Brasil começa a se estruturar ao longo de uma etapa histórica peculiar, a Ditadura militar brasileira (1964-1985), período marcado pela sucessiva perseguição de grupos considerados opositores ao regime político. Durante o período ditatorial no Brasil podemos observar um deslocamento dos mecanismos repressivos do Estado, inicialmente voltados ao combate de jovens, em sua maioria de classe média, e que ao final dos anos de 1980 voltaram-se para a baixa criminalidade (Souza, 2005) como exemplares ideais para medidas de controle, tortura e punição.

Jovchelovitch (2000) destaca que com o fim do regime militar no Brasil, aos poucos o envolvimento com tóxicos foi ganhando cada vez mais espaço na pauta jornalística, assim, com um novo elemento de risco no cenário social, os militares puderam manter seu lugar social, como os guardiões da ordem, que passava na década de 1990, a ser ameaçada pela crescente violência e criminalidade. "Nossos outros, os 'pobres', parecem ter sido vítimas da nossa pressa de marcar posições e nos distinguirmos, como elite, com marcas já purificadas do que rejeitamos como menor, inferior, inculto, tradicional e atrasado" (Zaluar, 1994a, p. 35). Esta pressa é explicita pelo conteúdo da Classe 1 (Envolvidos), onde apesar da descrição do contexto da justiça, as referências à oportunidade de defesa são mínimas, não parece haver uma mobilização por julgamentos justos, mas por condenações. 
Se os laços familiares parecem humanizar os criminosos, amenizando os processos de "demonização" e "desumanização" (Wacquant, 2008), próprios da construção seletiva implicada na objetivação dos objetos de representação social, vemos simultaneamente a naturalização da associação do contexto de pobreza com a criminalidade. Em suas pesquisas realizadas na década de 1980 em uma favela carioca, Zaluar (1994a) constata:

\footnotetext{
O noticiário policial, então já não comportava todas as notícias sobre a crescente criminalidade na cidade do Rio de Janeiro se espalhava por outras folhas, anunciando-se às vezes em manchetes de primeira página. O teor dessas notícias era claramente sensacionalista: a criminalidade incontida, a violência cada vez maior cometida durante os assaltos, o clima de guerra em que estavam envoltos os bairros pobres onde atuavam quadrilhas de traficantes de tóxicos (Zaluar, 1994a, p. 13).
}

Cada vez mais a associação entre criminalidade e pobreza é afirmada, construindo preconceitos e estereótipos. Assim, segundo Zaluar (1994a), a favela passa a representar o protótipo da desorganização, descivilização e criminalidade, considerado pela opinião pública e meios de comunicação como "antro de perigosos criminosos, assassinos em potencial, traficantes de tóxicos, etc." (Zaluar, 1994a, p. 10).

Relacionadas ao segundo conjunto de classes, "Problema doméstico", são encontrados variados registros de operações militares nas favelas, os "territórios da pobreza" (Coimbra, 2001b, p. 82), antros de miseráveis e signatários de mazelas sociais. No Brasil, estes territórios encontram-se profundamente associados ao contexto urbano, reflexo de cidades que cresceram desordenadamente, e passaram a não oferecer aos seus moradores recursos para a manutenção da qualidade de vida, estando submetidos a condições degradantes (Coimbra, 2001b). Além dos territórios da pobreza também eram configuradas as "classes perigosas" (Coimbra, 2001b, p.88) formada por todos aqueles que estivessem fora do mercado de trabalho.

\footnotetext{
... considerados "viciosos", por sua vez, por não pertencerem ao mundo do trabalho - uma das mais nobres virtudes enaltecida pelo capitalismo - e viverem no ócio, são portadores de delinqüência, são libertinos, maus pais, vadios. Representam um "perigo social" que deve ser erradicado; justificam-se, assim, as medidas coercitivas, já que são criminosos em potencial (Coimbra, 2001b, p. 91).
}

A composição do campo representacional denuncia a repetição de padrões de segregação entre grupos dominantes e subalternos, em que se destacam: norte-americanos e latino-americanos; consumidores e traficantes; vítimas e bandidos; classes médias e classes baixas. Estas separações, fruto dos processos de categorização, comparação e diferenciação social (Tajfel, 1982, 1983) podem conduzir a relações intergrupais de solidariedade, mas também de violência. Esta ambiguidade se deve à dimensão de grupo enquanto pertencimento psicológico, representado por múltiplas pertenças em constante mutação (Tajfel, 1983) - que abrirá brechas para identificações com grupos marginais. Portanto, as relações de categorização não necessariamente são separatistas ou excludentes, o reconhecimento da alteridade é próprio da dinâmica psicossocial, sem a qual seríamos apenas uma massa indiferenciada de indivíduos (Souza, 2004).

Para o enriquecimento do campo representacional foram necessários fundamentos do conhecimento científico, político e histórico acumulados no senso comum, que serviram como base para o processo de ancoragem dos saberes populares produzidos acerca do consumo e comércio de drogas ao longo da história, e apresentados no conteúdo da revista Veja. Desta forma, o novo objeto social precisou ser objetivado em determinados grupos sociais da realidade social brasileira, como forma de proteger os grupos sociais dominantes. 
"A grande novidade, o assustador, é a vizinhança, é a proximidade de nós - habitantes de zonas 'nobres' - desses 'perigosos'. É a sua presença tão perto das elites" (Coimbra, 2001b, p. 128 , grifo da autora).

Quando o tráfico de drogas é concebido como "coisa de favelado" - grupo social que é ao mesmo tempo integrado e segregado da dinâmica social mais ampla (Souza, 2004; Sawaia, 2008) - os consumidores da classe média e alta se mantêm a salvo da crítica social. São os pobres e favelados, porque "perigosos" (Coimbra, 2001b), que podem e precisam ser exterminados, e, neste sentido, o papel dos meios de comunicação no surgimento e na disseminação de estereótipos merece destaque. Assim, ao longo das décadas o processo de objetivação possibilitou a construção de um núcleo figurativo, que fornece ícones sobre o tráfico de drogas, materializando-o e tornando-o natural em nosso cotidiano. Este processo deixa claro que há grupos, locais e personagens específicos vinculados à realidade do tráfico de drogas.

O conhecimento que as pessoas têm sobre grupos que podem ser alvo de projeção é construído tanto por memórias coletivas, como pelas teorias que circulam na comunidade científica, nos meios de comunicação de massa e nas conversações do dia-a-dia .... Ainda que diferentes grupos, em uma sociedade, tenham diferentes 'depositários' para acusar, a ideologia dominante da sociedade tende a propagar imagens de alguns grupos específicos como seu 'outro' total (Joffe, 1994/2009, pp. 315-316).

Desta forma, o conhecimento social produzido sobre o tráfico de drogas parece compor dois conjuntos de elementos em constante negociação, que reproduzem a mesma lógica de organização. A clivagem no conteúdo do corpus (Problema doméstico x Drogas na Fronteira, Figura 1) aponta alguns dos mecanismos pelos quais determinados grupos, territórios e comportamentos passam a estar associados ao tráfico de drogas no Brasil. Inicialmente, a produção, a distribuição e o consumo de drogas foram claramente relacionados a dinâmicas observadas em realidades estrangeiras, mas a análise do conjunto de classes "Problema Doméstico" fornece elementos para a compreensão de como os atores brasileiros lidaram com o fenômeno. Portanto, notam-se elementos ou grupos que foram demonizados (Arbex Jr. \& Tognolli, 2004; Wacquant, 2008) ou responsabilizados pelo avanço do tráfico de drogas a nível global. Assim,

O problema aqui é o de como uma sociedade representa a si mesma e descobre em sua própria imagem uma fonte de ameaça, de contaminação e perigo. O problema então é de como a alteridade, na maior parte das vezes cuidadosamente mantida à distância, torna-se o centro das representações que uma sociedade desenvolve sobre si mesma (Jovchelovitch, 2000, p. 136).

O tráfico global de drogas encontra seus depositários nas regiões periféricas do mundo, já no nível local sua representação relaciona-se a "coisa de pobre", fenômeno relativo às periferias das grandes cidades. Há, portanto, uma mesma lógica de proteção endogrupal explicitada na construção de práticas e discursos que buscam afastar o risco implícito ao tráfico dos grupos sociais dominantes.

Com certeza, a proibição do uso de drogas e consequentemente a definição do comércio de drogas ilícitas como atividade criminosa, são elementos básicos para a representação social, pois possibilitam a aproximação destas atividades ao conjunto de crimes já conhecidos. Ainda assim, não se trata de um crime qualquer, envolve mercadorias específicas capazes de "corromper", e por isso, trata-se de uma fonte de risco social e potencial à saúde da população. Seu consumo é, portanto, atividade arriscada/prejudicial, podendo levar ao prazer ou a dependência, e neste sentido, o uso de drogas é o primeiro universo que negocia a composição de ideias sobre o tráfico de drogas. 
Quando o uso é diferenciado do tráfico de drogas, são sustentados mecanismos de proteção do grupo próprio, uma vez que nossa sociedade propõe o tratamento aos usuários e prisão aos traficantes. O número de reportagens que comprometem as classes economicamente favorecidas nos processos adjacentes ao tráfico de drogas é mínimo no corpus analisado, fato que pode explicar-se na medida em que revela um conteúdo conflituoso para a dinâmica das representações sociais sobre o tráfico de drogas difundidas pela revista Veja. Neste sentido, compreendemos que a mídia é importante instrumento de disseminação de versões dos fatos sociais, contribuindo para a construção do reservatório de significados atribuídos ao fenômeno, revelando, neste caso, personagens marginalizados e sem controle, que assolam o imaginário social e se tornam elementos fundamentais para a construção, manutenção e difusão de representações sociais sobre o tráfico de drogas.

\section{Conclusões}

Ao problematizar o papel da mídia como construtor e difusor de representações sociais, deparamo-nos com estereótipos fortemente difundidos, que cristalizam importantes ideias sobre fenômenos da dinâmica social. Foi possível identificar de forma exploratória como o semanário Veja tratou do tema tráfico de drogas ao longo de mais de 40 anos, a partir de um recorte do conjunto total de material produzido no período. Trata-se de um conteúdo lexical rico em dinâmicas sociais, que ora remetem a dinâmica nacional, ora falam das fronteiras e das problemáticas internacionais devidas ao tráfico. Vimos como os discursos de especialistas sobre o risco das drogas são acionados para ancorar o objeto em questão, justificando o combate e a marginalização daqueles que são materializados como seus responsáveis (produtores e moradores das favelas).

É importante reconhecer que o material analisado por esta pesquisa sofre influências políticas, ideológicas, históricas e econômicas, que marcam sua produção, e desta forma, esta pesquisa não revela saberes absolutos. O que identificamos através deste estudo são conhecimentos localizados em um grupo social específico, que apresenta sua versão da realidade e difunde ideias. Mesmo que os veículos de massa não sejam direcionados a um grupo social claramente delimitado, com certeza, sua estrutura não concebe espaço equivalente à manifestação de todos os grupos sociais de forma igualitária. Nesse caso, o conhecimento é emitido, consumido e disseminado a partir da perspectiva de classes dominantes em nossa sociedade, como assumido pelo próprio semanário ao traçar seu perfil de leitores. Assim, “Um jornal representa até certo ponto o mundo para um grupo de pessoas, caso contrário elas não o comprariam (...) o jornal se torna um indicador desta visão de mundo" (Bauer, Gaskell \& Allum, 2008, p. 22).

Deste modo, o material documental se mostra fonte profícua de dados para a pesquisa social, possibilitando outras leituras para além do cenário aqui destacado. Entendemos, portanto, que o tema revela lacunas e perspectivas que ainda podem ser exploradas em novos esforços de pesquisa para o enriquecimento do quadro aqui apresentado.

\section{Referências}

Almeida, M. F. L. (2009). Veja sob censura: 1968-1976. São Paulo: Jaboticaba. 
Andrade, M. A. A. (2000). A identidade como representação e a representação da identidade. In A. S. P. Moreira \& D. C. Oliveira (Orgs.). Estudos interdisciplinares de representação social (2a ed., pp.141-149). Goiânia: AB.

Araújo, T. (2012). Almanaque das drogas. São Paulo: Leya.

Arbex, J., Jr., \& Tognolli, C. J. (2004). O século do crime. São Paulo, SP: Boitempo.

Avelino, V. P. (2010). A evolução da legislação brasileira sobre drogas. Jus Navigandi, 2440, 1-4. Recuperado em 20 janeiro, 2013, de http://jus.com.br/revista/texto/14470.

Bauer, M. W., \& Aarts, B. (2002). A construção do corpus: um princípio para a coleta de dados qualitativos. In M. W. Bauer \& G. Gaskell (Orgs.). Pesquisa qualitativa com texto, imagem e som: um manual prático (2a ed., pp. 39-63). Petrópolis: Vozes.

Bauer, M. W., Gaskell, G. \& Allum, N. C. (2008). Qualidade, Quantidade e interesses do conhecimento. In M. W. Bauer \& G. Gaskell (Orgs.). Pesquisa qualitativa com texto, imagem e som: um manual prático. (pp. 1736). Petrópolis: Vozes.

Brasil (2009). Relatório brasileiro sobre drogas. In V. Duarte, V. A. Stempliuk \& L. P. B. (Orgs.). Secretaria Nacional de Políticas sobre Drogas/ IME USP. P. C. A. Brasília: SENAD.

Chauí, M. (1980). A não-violência do brasileiro, um mito interessantíssimo. Almanaque: Cadernos de literatura e Ensaio Brasiliense, 11, 16-24.

Coimbra, C. B. M. (2001a). A Denúncia de Tortura da Perspectiva da Pessoa Afetada. Recuperado em 05 fevereiro, 2013, de http://www.slab.uff.br/textos/texto43.pdf.

Coimbra, C. B. M. (2001b). Operação Rio: o mito das classes perigosas: um estudo sobre a violência urbana, a mídia impressa e os discursos de segurança pública. Rio de Janeiro: Oficina do Autor. Niterói: Intertexto.

Cruz Neto, O., Moreira, M. R., \& Sucena, L. F. M. (2001). Nem soldados nem inocentes: juventude e tráfico de drogas no Rio de Janeiro. Rio de Janeiro: Fiocruz.

De Alba, M. (2004). El método ALCESTE y su aplicación al estudio de las representaciones sociales del espacio urbano: el caso de la Ciudad de México. Papers on social representations, 13(1), 01-20.

Escohotado, A. (1998). Historia General de Las Drogas. Madri: Editorial Espasa Calpe.

Feffermann, M. (2006). Vidas arriscadas: o cotidiano de jovens trabalhadores do tráfico. Petrópolis: Vozes.

Fraga, P. C. P. (2003). Da favela ao sertão: juventude, narcotráfico e institucionalidade. In P. C. P. Fraga \& J. A. S. Iulianelli. Jovens em tempo real (pp. 117-147). Rio de Janeiro: DP\&A.

Grupo Abril. (2011). Perfil de leitores. Recuperado em 6, novembro, 2011, de http://www.publiabril.com.br/tabelas-gerais/revistas/perfil-dos-leitores/.

Jodelet, D. (2001). Representações Sociais: um domínio em expansão. In D. Jodelet. As Representações Sociais. (pp. 17-44). Rio de Janeiro: EdUERJ.

Joffe, H. (1994/2009). “Eu não”, "o meu grupo não”: representações sociais transculturais da AIDS. In P. Guareschi \& S. Jovchelovitch (Orgs.). Textos em representações sociais (Coleção Psicologia Social, pp. 297-323). Petrópolis: Vozes.

Jovchelovitch, S. (2000). Representações sociais e esfera pública: a construção simbólica dos espaços públicos no Brasil (Coleção Psicologia Social). Petrópolis: Vozes.

Karam, M. L. (1996). A esquerda punitiva. Revista Discursos Sediciosos: crime, direito e sociedade, 1(1), 79-92.

Kronberguer, N., \& Wagner, W. (2008). Palavras-chave em contexto: análise estatística de textos. In M. W. Bauer \& G. Gaskell (Orgs.). Pesquisa qualitativa com texto, imagem e som: um manual prático (pp. 416441). Petrópolis: Vozes.

Menandro, M. C. S., Trindade, Z. A., \& Almeida, A. M. O. (2010). Gente jovem reunida: representações sociais de adolescência/juventude em textos jornalísticos. Vitória: GM Gráfica e Editora.

Moscovici, S. (1978). A representação social da psicanálise. Rio de Janeiro: Zahar (Trabalho original publicado em 1961). 
Moscovici, S. (2009). Representações Sociais: investigações em psicologia social (Coleção Psicologia Social). Petrópolis: Vozes.

Moscovici, S. (2012). A psicanálise, sua imagem e seu público (Sônia Fuhrmann, trad., Coleção Psicologia Social). Petrópolis: Vozes (Trabalho original publicado em 1961).

Noto, A. R., \& Galduróz, J. C. F. (1999). O uso de drogas psicotrópicas e a prevenção no Brasil. Ciência \& Saúde coletiva, 4(1), 145-151. Recuperado em 12 junho, 2009, de http://www.scielo.br/scielo.php?script=sci_arttext\&pid=\$1413-81231999000100012\&lng=en\&nrm=iso.

Oliveira, D. C., Gomes, A. M. T., \& Marques, S. C. (2005). Análise estatística de dados textuais na pesquisa das representações sociais: alguns princípios e uma aplicação ao campo da saúde. In M. S. S. Menin \& A. M. Shimizu (Orgs.) Experiência e representação social: questões teóricas e metodológicas (pp. 157-199). São Paulo: Casa do Psicólogo.

Olson, D. R. (1997). O mundo no papel: as implicações conceituais e cognitivas da leitura e da escrita. São Paulo: Ática.

Ordaz, O., \& Vala, J. (2000). Objetivação e Ancoragem das Representações Sociais do Suicídio na Imprensa Escrita. In A. S. P. Moreira \& D. C. Oliveira. Estudos Interdisciplinares de representação social (pp. $87-$ 114). Goiânia: AB.

Pedrosa, R. M. (2012). Mulheres criminosas: representações sociais sobre mulher e crime em dois jornais populares. Dissertação de Mestrado, Faculdade de Filosofia e Ciências Humanas, Programa de PósGraduação em Psicologia, Universidade Federal de Minas Gerais, Belo Horizonte, MG, Brasil.

Ramos, S., \& Paiva, A. (2007). Mídia e violência: tendências na cobertura de criminalidade e segurança no Brasil. Rio de Janeiro: IUPERJ.

Rodrigues, T. (2002). Limiares. VERVE: Revista Semestral do NU-SOL - Núcleo de Sociabilidade Libertária/Programa de Estudos Pós-Graduados em Ciências Sociais, maio(1), 65-74. São Paulo: 0 Programa.

Rodrigues, T. (2003). Narcotráfico: uma guerra na guerra. São Paulo: Desatino.

Santos, M. F. S. (2000). Representação Social e Identidade. In A. S. P. Moreira \& D. C. Oliveira (Orgs.). Estudos interdisciplinares de representação social (2ª ed., pp. 151-159). Goiânia: AB.

Sawaia. B. (2008). Introdução: Exclusão ou Inclusão perversa? In B. Sawaia (Org.). As artimanhas da exclusão: análise psicossocial e ética da desigualdade social (pp. 7-13). Petrópolis: Vozes.

Souza, L. (2004). Processos de categorização e identidade: solidariedade, exclusão e violência. In L. Souza \& Z. A. Trindade (Orgs.). Violência e exclusão: convivendo com paradoxos (pp. 57-74). São Paulo: Casa do Psicólogo.

Souza, L. (2005). Processos de identidade social: da intolerância e violência à utopia solidária. In Z. Trindade \& L. Souza (Eds.). Anais do Simpósio Nacional de psicologia social e do desenvolvimento humano - X Encontro Nacional do PROCAD/Psicologia-CAPES, Vitória, ES, Brasil. Recuperado em 19 dezembro, 2012, de www.simpsodes.pro.br.

Souza, L., \& Menandro, P. R. M. (2007). Pesquisa documental em psicologia: a máquina do tempo. In M. M. P. Rodrigues \& P. R. M. Menandro (Orgs.) Lógicas Metodológicas: trajetórias de pesquisa em psicologia. (pp. 151-174). Vitória: UFES - Programa de Pós-Graduação em Psicologia / GM Gráfica Editora.

Tajfel, H. (1982). Comportamento intergrupo e psicologia social da mudança. In: Knoke, A., et al. Mudança social e psicologia social (pp. 13-24). Lisboa: Livros Horizonte.

Tajfel, H. (1983). Grupos humanos e categorias sociais (Lígia Amâncio, trad., Vol. II, Coleção Horizonte de Psicologia). Lisboa: Livros Horizonte.

Vargas, E. V. (2008). Fármacos e outros objetos sócio-técnicos: notas para uma genealogia das drogas. In B. C. Labate, S. Goulart, M. Fiore, E. MacRae \& H. Carneiro (Orgs.) Drogas e cultura: novas perspectivas (pp. 41-54). Salvador: EDUFBA.

Velho, G. (1994). A dimensão cultural e política dos mundos das drogas. In A. Zaluar (Org.). Drogas e cidadania: repressão ou redução de danos (pp. 23-29). São Paulo: Editora Brasiliense. 
Zaffaroni, E. R. (1996). Crime organizado: uma categorização frustrada. Revista Discursos Sediciosos: crime, direito e sociedade, 1(1), 45-68.

Zaluar, A. (1994a). A máquina e a revolta: as organizações populares e o significado da pobreza. São Paulo: Editora Brasiliense.

Zaluar, A. (1994b). Condomínio do diabo. Rio de Janeiro: Revan - EdUERJ.

Zaluar, A. (2004). Integração perversa: pobreza e tráfico de drogas. Rio de Janeiro: Editora FGV.

Wagner, W. (2000). Sócio-gênese e características das Representações Sociais. In A. S. P. Moreira \& D.C. Oliveira (Orgs.). Estudos interdisciplinares de representação social (pp. 3-25). Goiânia: AB.

Wacquant, L. (2008). As duas faces do gueto (P. C. Castanheira, trad.). São Paulo: Boitempo. 